\title{
Correction to: The Myth of McMindfulness
}

\section{Bhikkhu Anālayo $^{1}$}

Published online: 29 May 2020

(C) The Author(s) 2020

\section{Correction to: Mindfulness \\ https://doi.org/10.1007/s12671-019-01264-x}

The article "The Myth of McMindfulness," written by Bhikkhu Anālayo, was originally published electronically on the publisher's internet portal on 10 December 2019 without open access.

With the author(s)' decision to opt for Open Choice, the copyright of the article changed on May 2020 to (C) The Author(s) 2020, and the article is forthwith distributed under a Creative Commons Attribution 4.0 International License (https://creativecommons.org/licenses/by/4.0/), which permits use, sharing, adaptation, distribution, and reproduction in any medium or format, as long as you give appropriate credit to the original author(s) and the source, provide a link to the Creative Commons license, and indicate if changes were made.
Open Access This article is licensed under a Creative Commons Attribution 4.0 International License, which permits use, sharing, adaptation, distribution and reproduction in any medium or format, as long as you give appropriate credit to the original author(s) and the source, provide a link to the Creative Commons licence, and indicate if changes were made. The images or other third party material in this article are included in the article's Creative Commons licence, unless indicated otherwise in a credit line to the material. If material is not included in the article's Creative Commons licence and your intended use is not permitted by statutory regulation or exceeds the permitted use, you will need to obtain permission directly from the copyright holder. To view a copy of this licence, visit http://creativecommons.org/licenses/by/4.0/.

The online version of the original article can be found at https://doi.org/ 10.1007/s12671-019-01264-x

Bhikkhu Anālayo

1 Barre Center for Buddhist Studies, 149 Lockwood Road,

Barre, MA 01005, USA 